\title{
Aplikasi Dosis Vermikompos dan Urea Pada Tanaman Kedelai Varietas Anjasmoro di Tanah Berpasir
}

\section{(Application of Vermicompost and Urea on Anjasmoro Soybean Variety in Sandy Soil)}

\author{
Hesti Pujiwati ${ }^{\star}$, Widodo ${ }^{1}$, Wuri Prameswari ${ }^{1}$, Umi Salamah ${ }^{1}$, Leonardo Dharmawangsa ${ }^{1}$, Edi Susilo ${ }^{2}$, \\ Muhimmatul Husna ${ }^{1}$
}

(Diterima Januari 2021/Disetujui September 2021)

\begin{abstract}
ABSTRAK
Luas areal tanam yang sempit merupakan masalah dalam memenuhi kebutuhan akan kedelai. Produksi kedelai skala nasional dapat diupayakan melalui perluasan areal tanam. Solusi yang ditawarkan adalah memanfaatkan areal tanah berpasir yang masih luas untuk budi daya kedelai. Penelitian dimulai bulan September-November 2020 di rumah kaca Laboratorium Agronomi, Universitas Bengkulu. Tujuan penelitian ini ialah menemukan dosis urea dan vermikompos terbaik untuk pertumbuhan dan hasil kedelai di tanah berpasir. Rancangan percobaan yang digunakan ialah Rancangan Acak Kelompok Lengkap dengan dua faktor dan 3 ulangan yang meliputi: dosis urea ( $U_{0}=0$ kg ha $\left.1, U_{1}=50 \mathrm{~kg} \mathrm{ha}^{-1}, \mathrm{U}_{2}=100 \mathrm{~kg} \mathrm{ha}^{-1}, \mathrm{U}_{3}=150 \mathrm{~kg} \mathrm{ha}^{-1}\right)$ dan dosis vermikompos $\left(\mathrm{K}_{0}=0\right.$ ton ha ${ }^{-1}, \mathrm{~K}_{1}=5 \mathrm{ton} \mathrm{ha}^{-1}, \mathrm{~K}_{2}=10$ ton $\mathrm{ha}^{-1}, \mathrm{~K}_{3}=15$ ton ha-1). Variabel pengamatan meliputi pertumbuhan dan hasil tanaman. Vermikompos dan tanah dianalisis sebelum penelitian. Hasil penelitian menunjukkan terdapat interaksi antara dosis urea dan vermikompos. Aplikasi urea $100 \mathrm{~kg} \mathrm{ha}^{-1}$ dan vermikompos 10 ton ha-1 memberikan tinggi tanaman kedelai terbaik dan perlakuan urea $150 \mathrm{~kg} \mathrm{ha}^{-1}$ dan vermikompos 15 ton ha-1 membentuk cabang terbanyak. Aplikasi vermikompos 15 ton hadengan urea $50 \mathrm{~kg} \mathrm{ha}^{-1}$ memberikan hasil tertinggi untuk jumlah polong total dan bobot biji.
\end{abstract}

Kata kunci: kedelai, tanah berpasir, urea, vermikompos

\section{ABSTRACT}

The low area for soybean plantation is still a major problem in meeting soybean needs. One of the efforts to increase national soybean production is by expanding the planting area by utilizing the sandy soil area that is still not used for soybean cultivation. This research was conducted from September-November 2020 in a greenhouse of the Agronomy Laboratory, Bengkulu University. This study aims to obtain the best dose of urea and vermicompost for the growth and yield of soybean in sandy soil. The research design used a completely randomized block design with two factors and 3 replications. The first factor was the dose of urea consisting of four levels, namely $\mathrm{U}_{0}=0 \mathrm{~kg}$ $\mathrm{ha}^{-1}, \mathrm{U}_{1}=50 \mathrm{~kg} \mathrm{ha}^{-1}, \mathrm{U}_{2}=100 \mathrm{~kg} \mathrm{ha}^{-1}$, and $\mathrm{U}_{3}=150 \mathrm{~kg} \mathrm{ha}^{-1}$. The second factor was the dose of vermicompost, namely $\mathrm{K}_{0}=0$ ton ha-1, $\mathrm{K}_{1}=5$ tons ha-1, $\mathrm{K}_{2}=10$ ton ha-1, and $\mathrm{K}_{3}=15$ ton ha-1. The measured variables were the plant growth and the yield. Soil and vermicompost analyses were carried out before the study. The results showed that there was an interaction between the vermicompost and the urea dosages. The $100 \mathrm{~kg} \mathrm{ha}^{-1}$ urea and the 10 ton havermicompost treatment gave the highest plant height. The $150 \mathrm{~kg} \mathrm{ha}^{-1}$ urea dan the 15 ton ha-1 vermicompost

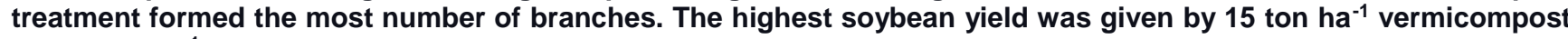
and $50 \mathrm{~kg} \mathrm{ha}^{-1}$ urea to the total pod and the seed weight.

Keywords: sandy soil, soybean, urea, vermicompost

\section{PENDAHULUAN}

Salah satu komoditas pangan di Indonesia adalah kedelai (Glycine max) yang bermanfaat sebagai sumber pangan nabati serta mengandung protein tinggi sampai $40 \%$. Kedelai dimanfaatkan untuk

1 Program Studi Agroteknologi, Jurusan Budidaya Pertanian, Fakultas Pertanian, Universitas Bengkulu, Jl. Raya Kadang Limun, Bengkulu, 38371

2 Program Studi Agroteknologi, Fakultas Pertanian, Universitas Ratu Samban, Jl. Jenderal Sudirman No. 87, Arga Makmur, Bengkulu Utara, 38618

* Penulis Korespondensi:

E-mail: hesti_pujiwati@unib.ac.id keperluan industri, pangan, dan pakan. Kedelai pada umumnya diolah menjadi makanan seperti tempe, tahu, kecap, susu, dan tauco (Pambudi 2013). Data BPS 2015 menunjukkan bahwa konsumsi ratarata/orang/tahun di Indonesia adalah 6,99 kg untuk olahan tempe dan $7,51 \mathrm{~kg}$ untuk olahan tahu (Kementerian Pertanian 2016).

Alternatif untuk memenuhi kebutuhan kedelai ialah dengan meningkatkan luas areal tanam. Salah satu solusinya ialah dengan memanfaatkan areal tanah berpasir untuk budi daya kedelai. Tanah berpasir banyak dijumpai di lahan pesisir dan dapat dikembangkan untuk lahan budi daya kedelai. Potensi lahan pesisir di antaranya ialah lahan yang cukup luas, per- 
mukaan lahan yang relatif datar, bebas banjir, intensitas penyinaran matahari maksimum, serta pengolahan lahan relatif tidak sulit, tetapi rendah dalam hal daya ikat air, kapasitas tukar kation (KTK), C-organik, bahan organik, kandungan $\mathrm{Ca}, \mathrm{N}$, dan $\mathrm{K}$. Demikian pula luas permukaan kecil dan pori besar, yang berakibat rendahnya kemampuan menahan air dan hara tersedia (Rajiman et al. 2008).

Unsur hara $\mathrm{N}$ pada tanah dapat ditambahkan dan sifat fisika dan kimia tanah berpasir dapat diperbaiki dengan pemupukan anorganik (urea) dan ditambah pupuk organik berupa vermikompos. Unsur hara nitrogen berupa $\mathrm{NO}_{3}{ }^{-}$dan $\mathrm{NH}_{4}{ }^{+}$dalam tanah sangat sedikit tersedia bagi tanaman karena mudah terlindikan (leaching), run off, dan tidak terikat kuat pada struktur tanah. Kendala tersebut diatasi dengan menambahkan unsur nitrogen guna membantu pertumbuhan dan perkembangan tanaman kedelai.

Beberapa hasil penelitian menunjukkan terdapat pengaruh positif aplikasi pemupukan anorganik jika ditambah dengan vermikompos. Berdasarkan temuan Hindersah et al. (2019), aplikasi vermikompos dengan NPK dapat meningkatkan tinggi tanaman kentang pada tanah andisol serta meningkatkan ketersediaan hara $\mathrm{P}$ dan $\mathrm{pH}$ tanah dengan kandungan hara vermikompos yang digunakan 2,03\% $\mathrm{N}, 1,16 \% \mathrm{P}_{2} \mathrm{O}_{5}$ dan $0,54 \% \mathrm{~K}_{2} \mathrm{O}$. Vermikompos juga dapat meningkatkan kadar hara $\mathrm{N}$ pada tanaman brokoli (Tauhidah et al. 2018). Selain meningkatkan unsur hara tersedia, vermikompos berguna untuk menahan air yang ada di dalam media berpasir. Menurut Munnoli dan Bhosle (2011), penambahan vermikompos ke tanah dapat meningkatkan kapasitas menahan air dan menjaga evaporasi seminimum mungkin karena sifat vermikompos yang berfungsi sebagai absorben. Meningkatnya kapasitas menahan air dapat mengurangi kemungkinan kekeringan pada kedelai.

Meskipun kedelai merupakan tanaman pangan yang cocok di dataran rendah, komoditas ini belum banyak dibudidayakan di tanah berpasir. Penelitian ini menjadi terobosan bahwa lahan berpasir berpotensi besar untuk dikembangkan dengan metode pemupukan guna menyokong pertumbuhan dan perkembangan kedelai. Penelitian ini bertujuan mendapatkan dosis urea dan vermikompos terbaik untuk pertumbuhan dan hasil kedelai yang dibudidayakan di tanah berpasir.

\section{METODOLOGI PENELITIAN}

Penelitian dilaksanakan pada bulan September sampai November 2020, di rumah kaca Laboratorium Agronomi, Universitas Bengkulu, Kota Bengkulu. Bahan yang digunakan adalah benih kedelai varietas Anjasmoro, urea, vermikompos, tanah berpasir, pupuk urea, dan karbofuran. Metode penelitian menggunakan Rancangan Acak Kelompok Lengkap yang terdiri atas dua faktor, yaitu dosis urea, $\mathrm{U}_{0}=0 \mathrm{~kg} \mathrm{ha}^{-1} ; \mathrm{U}_{1}=50 \mathrm{~kg}$ ha-1 $; \mathrm{U}_{2}=100 \mathrm{~kg} \mathrm{ha}^{-1} ; \mathrm{U}_{3}=150 \mathrm{~kg} \mathrm{ha}^{-1}$, dan dosis vermikompos $\mathrm{K}_{0}=0$ ton ha- ${ }^{-1} ; \mathrm{K}_{1}=5$ ton ha- ${ }^{-1} ; \mathrm{K}_{2}=10$ ton ha ${ }^{-1} ; K_{3}=15$ ton ha ${ }^{-1}$. Terdapat 16 kombinasi perlakuan dengan 3 ulangan.

Media tanah berpasir diambil dari lahan pesisir di Kuala Alam, Kecamatan Gading Cempaka, Kota Bengkulu. Sanpel tanah berpasir diambil dengan cara membersihkan terlebih dahulu gulma yang berada di sekitar lahan kemudian digali menggunakan cangkul dengan kedalaman $20 \mathrm{~cm}$. Tanah berpasir yang telah diambil dikeringanginkan hingga homogen. Selanjutnya tanah diisikan ke dalam polibag berukuran $17 \mathrm{~cm}$ $x 40 \mathrm{~cm}$, kemudian diisi dengan media yang telah kering-angin dan dibersihkan dari serasah sebanyak 5 $\mathrm{kg}$ polibag-1.

Analisis kimia dan tekstur tanah awal dilakukan di Laboratorium Departemen IImu Tanah dan Sumber daya Lahan, Fakultas Pertanian, Institut Pertanian Bogor. Uji C organik berdasarkan Walkey and Black, uji $\mathrm{N}$ total (Kejdhal), P tersedia (Bray I), K (Flamefotometer), $\mathrm{pH}$ (elektrometris) dan uji tekstur menggunakan hidrometer. Sedangkan uji salinitas tanah diuji di laboratorium ilmu tanah, Fakultas Pertanian, Universitas Bengkulu menggunakan nilai DHL.

Sebelum ditanam, benih diberi Rhizobium sp. serta pada lubang tanam diberi insektisida yang berbahan aktif karbofuran agar benih tidak dimakan oleh semut atau serangga yang ada di dalam tanah. Pupuk diaplikasikan sesuai dengan perlakuan. Untuk urea $50 \mathrm{~kg}$ ha $^{-1}$ ditimbang $0,31 \mathrm{~g}_{\text {polibag }}{ }^{-1}$, unyuk urea $100 \mathrm{~kg} \mathrm{ha}$ ${ }^{1}$ ditimbang $0,62 \mathrm{~g}^{-1}$ polibag $^{-1}$, dan untuk urea $150 \mathrm{~kg} \mathrm{ha}^{-}$ 1 ditimbang $0,93 \mathrm{~g} \mathrm{polibag}^{-1}$. Untuk vermikompos 5 ton ha $^{-1}$ ditimbang $32,25 \mathrm{~g}_{\text {polibag }}{ }^{-1}$, untuk vermikompos 10 ton ha- ${ }^{-1}$ ditimbang $62,5 \mathrm{~g}$ polibag $^{-1}$, dan untuk vermikompos 15 ton ha- ditimbang $94,50 \mathrm{~g}^{-1}$ polibag ${ }^{-1}$. Untuk tambahan pupuk dasar $\mathrm{KCl}$ dan SP-36 sebanyak $150 \mathrm{~kg} \mathrm{ha}^{-1}$ ditimbang 0,93 polibag $^{-1}$.

Variabel yang diamati adalah tinggi tanaman $(\mathrm{cm})$, jumlah daun (helai), jumlah cabang (cabang), jumlah polong isi, jumlah polong hampa, jumlah polong total, bobot biji, bobot kering tajuk, bobot kering akar, jumlah bintil akar, bobot bintil akar, dan tingkat kehijauan daun. Data dianalisis menggunakan analisis varians (ANOVA) taraf $5 \%$. Apabila terdapat pengaruh nyata maka uji dilanjutkan dengan membandingkan antarrerata menggunakan uji Duncan (DMRT).

\section{HASIL DAN PEMBAHASAN}

Berdasarkan analisis laboratorium, media tanam berupa tanah berpasir pada penelitian ini mengandung C-organik $6,13 \%$ (sangat tinggi), N $0,04 \%$ (sangat rendah), $\mathrm{P} 19,84 \mathrm{ppm}$ (sangat tinggi), $\mathrm{K}_{2} \mathrm{O} 13 \mathrm{cmol}^{(+)}$ $\mathrm{kg}^{-1}$ (rendah), Na 0,08 $\mathrm{cmol}^{(+)} \mathrm{kg}^{-1}$ (rendah), kandungan pasir $91,32 \%$ (sangat tinggi), debu 1,95\% (rendah), dan liat $6,73 \%$ (rendah) Hasil analisis tersebut menggambarkan bahwa kandungan $\mathrm{N}$ dan $\mathrm{K}$ rendah tetapi tidak pada $P$. Namun kebutuhan tanaman kedelai pada hara makro khususnya $\mathrm{N}, \mathrm{P}$, dan $\mathrm{K}$ harus tercukupi. Kekurangan unsur tersebut akan mengakibatkan pertumbuhan tanaman terhambat 
(Afandi et al. 2017). Berdasarkan hasil uji salinitas, tanah tidak tergolong salin dengan kadar garam 33,66 ppm atau $0,05 \mathrm{mS} \mathrm{cm}^{-1}$. Vermikompos yang diaplikasikan sebagai pupuk organik mengandung hara tinggi dengan $\mathrm{pH}$ netral $(7,3)$, C-organik $26,16 \%$, $\mathrm{N}$ total $1,65 \%, \mathrm{P}$ total $1,08 \%, \mathrm{~K} 2,04 \%$, dan nisbah $\mathrm{C} / \mathrm{N}$ $15,87$.

Pengaruh dosis pupuk vermikompos dan urea beragam pada setiap variabel. Aplikasi pupuk vermikompos berpengaruh nyata pada tinggi tanaman dan hasil kedelai pada variabel jumlah polong isi, jumlah polong hampa, jumlah polong total, bobot biji, kering tajuk, dan jumlah bintil akar. Akan tetapi, aplikasi vermikompos tidak berpengaruh nyata pada jumlah daun, jumlah cabang, bobot kering akar, dan bobot bintil akar yang terbentuk. Dosis urea nyata memengaruhi pertumbuhan dan hasil kedelai, tetapi tidak nyata memengaruhi jumlah polong hampa. Hasil analisis anava taraf $5 \%$ perlakuan vermikompos dan urea tertera pada Tabel 1.
Terdapat interaksi antara perlakuan dosis vermikompos dan pupuk urea berdasarkan analisis sidik ragam pada semua variabel kecuali jumlah daun, bobot kering akar, jumlah bintil, dan bobot bintil akar. Dosis urea $100 \mathrm{~kg} \mathrm{ha}^{-1}$ dan vermikompos 10 ton ha-1 $\left(\mathrm{K}_{2} \mathrm{U}_{2}\right)$ memberikan tinggi tanaman kedelai terbaik (108,75 $\mathrm{cm}$ ), sedangkan jumlah cabang terbanyak terbentuk pada kombinasi perlakuan urea $150 \mathrm{~kg} \mathrm{ha}^{-1}$ dan vermikompos 15 ton ha-1 $\left(\mathrm{K}_{3} \mathrm{U}_{3}\right)$ (Tabel 2).

Interaksi vermikompos 15 ton ha-1 urea $50 \mathrm{~kg} \mathrm{ha}^{-1}$ $\left(\mathrm{K}_{3} \mathrm{U}_{1}\right)$ menghasilkan variabel hasil tertinggi, yaitu jumlah polong isi, jumlah polong, dan bobot biji, dan tidak berbeda nyata dengan kombinasi perlakuan dengan dosis urea $100 \mathrm{~kg} \mathrm{ha}^{-1}$ dan $150 \mathrm{~kg} \mathrm{ha}^{-1}$ dan kombinasi $\mathrm{K}_{2} \mathrm{U}_{2}$. Hasil kedelai (bobot biji) yang diperoleh pada vermikompos 15 ton $\mathrm{ha}^{-1}$ dan urea 50 $\mathrm{kg} \mathrm{ha}^{-1}\left(\mathrm{~K}_{3} \mathrm{U}_{1}\right)$ adalah 26,18 $\mathrm{g}$ atau setara dengan 3,47 ton ha $^{-1}$. Nilai tersebut lebih tinggi $54,2 \%$ dari potensi hasil kedelai varietas Anjasmoro pada deskripsi varietasnya, yaitu antara 2,03 dan 2,25 ton ha-1

Tabel 1 Rekapitulasi pertumbuhan dan hasil kedelai akibat perlakuan vermikompos dan urea yang berbeda di tanah berpasir

\begin{tabular}{lccc}
\hline \multicolumn{1}{c}{ Variabel pengamatan } & Pupuk vermikompos & Urea & Interaksi \\
\hline Tinggi tanaman $(\mathrm{cm})$ & $0,0030^{* *}$ & $<, 0001^{* *}$ & $<, 0001^{* *}$ \\
Jumlah daun & $0,3170^{\mathrm{tn}}$ & $0,0016^{* *}$ & 0,3525 tn \\
Jumlah cabang & $0,0708^{\text {tn }}$ & $0,0005^{* *}$ & $0,0025^{* *}$ \\
Jumlah polong isi & $0,0016^{* *}$ & $0,0002^{* *}$ & $0,0267^{* *}$ \\
Jumlah polong hampa & $0,0304^{*}$ & $0,1551^{\text {tn }}$ & $0,0068^{* *}$ \\
Jumlah polong total & $0,0031^{* *}$ & $0,0002^{* *}$ & $0,0058^{* *}$ \\
Bobot biji (g) & $0,0016^{* *}$ & $0,0002^{* *}$ & $0,0106^{* *}$ \\
Bobot kering tajuk $(\mathrm{g})$ & $0,0003^{* *}$ & $<, 0001^{* *}$ & 0,0777 tn \\
Bobot kering akar $(\mathrm{g})$ & $0,1438^{\text {tn }}$ & $0,0020^{* *}$ & 0,0615 tn \\
Jumlah bintil akar & $0,0109^{* *}$ & $<, 0001^{* *}$ & 0,6539 tn \\
Bobot bintil akar $(\mathrm{g})$ & $0,2468^{\text {tn }}$ & $<, 0001^{* *}$ &
\end{tabular}

Keterangan $={ }^{* *}$ : berpengaruh sangat nyata; ${ }^{*}$ : berpengaruh nyata; tn: tidak nyata pada taraf $5 \%$

Tabel 2 Interaksi perlakuan dosis urea dan vermikompos di tanah berpasir

\begin{tabular}{|c|c|c|c|c|c|c|c|}
\hline Perlakuan & $\begin{array}{c}\text { Tinggi } \\
\text { tanaman } \\
(\mathrm{cm}) \\
\end{array}$ & $\begin{array}{c}\text { Jumlah } \\
\text { cabang } \\
\text { (cabang) }\end{array}$ & $\begin{array}{l}\text { Jumlah } \\
\text { polong isi }\end{array}$ & $\begin{array}{l}\text { Jumlah } \\
\text { polong } \\
\text { hampa }\end{array}$ & $\begin{array}{c}\text { Jumlah } \\
\text { polong total }\end{array}$ & $\begin{array}{l}\text { Bobot biji } \\
\text { (g) }\end{array}$ & $\begin{array}{c}\text { Bobot kering } \\
\text { tajuk } \\
\text { (g) }\end{array}$ \\
\hline KOUO & $62,25 \mathrm{e}$ & $30,00 \mathrm{c}$ & 24,50 ef & $10,00 a b c$ & 25,50 ef & 7,14 ef & $3,51 \mathrm{e}$ \\
\hline KOU1 & $95,50 \mathrm{abcd}$ & $30,00 \mathrm{c}$ & 35,00 def & $10,00 a b c$ & 36,00 def & 10,08 def & 9,15 cde \\
\hline KoU2 & $90,50 \mathrm{~cd}$ & $50,00 a b$ & $78,00 a b$ & $0,50 \mathrm{bc}$ & $78,50 a b$ & $21,98 a b$ & $16,83 a b$ \\
\hline KOU3 & $96,25 a b c$ & $45,00 a b$ & $64,50 \mathrm{abcd}$ & $20,00 a b c$ & $66,50 \mathrm{abcd}$ & $18,62 \mathrm{abcd}$ & $14,22 \mathrm{abc}$ \\
\hline K1U0 & $58,50 \mathrm{e}$ & $40,00 \mathrm{bc}$ & 46,50 bcdef & $25,00 a b$ & 49,00 bcdef & 13,72 bcdf & $8,50 \mathrm{cde}$ \\
\hline K1U1 & $94,50 \mathrm{bcd}$ & $45,00 \mathrm{ab}$ & 46,00 bcdef & $0,00 \mathrm{c}$ & 46,00 bcdef & 12,88 bcdf & $7,01 \mathrm{de}$ \\
\hline K1U2 & $105,60 a b$ & $40,00 \mathrm{bc}$ & 54,00 bcde & $30,00 \mathrm{a}$ & 57,00 bcde & 15,96 bcde & $12,27 \mathrm{bcd}$ \\
\hline K1U3 & 63,80 e & $40,00 \mathrm{bc}$ & 24,00 ef & $25,00 a b$ & 26,50 ef & 7,42 ef & $5,38 \mathrm{de}$ \\
\hline K2U0 & $63,30 \mathrm{e}$ & $30,00 \mathrm{c}$ & $15,00 \mathrm{f}$ & $10,00 a b c$ & $16,00 \mathrm{f}$ & $4,48 \mathrm{f}$ & $2,78 \mathrm{e}$ \\
\hline K2U1 & $107,00 a b$ & $50,00 a b$ & 24,00 ef & $15,00 a b c$ & 25,50 ef & 7,14 ef & $5,97 \mathrm{de}$ \\
\hline K2U2 & $108,75 \mathrm{a}$ & $55,00 a b$ & $76,50 a b$ & $30,00 \mathrm{a}$ & $79,50 a b$ & $22,26 a b$ & $17,47 a b$ \\
\hline K2U3 & $87,10 \mathrm{~cd}$ & $45,00 \mathrm{ab}$ & 42,00 cdef & $10,00 a b c$ & 43,00 cdef & 12,04 cdef & $8,82 \mathrm{cde}$ \\
\hline K3U0 & $63,00 \mathrm{e}$ & $40,00 \mathrm{bc}$ & 40,00 cdef & $10,00 a b c$ & 41,00 cdef & 11,48 cdef & $6,71 \mathrm{de}$ \\
\hline K3U1 & $84,80 \mathrm{~cd}$ & $45,00 \mathrm{bc}$ & $92,50 \mathrm{a}$ & $10,00 a b c$ & $93,50 \mathrm{a}$ & $26,18 \mathrm{a}$ & $20,15 a$ \\
\hline K3U2 & $82,05 d$ & $40,00 \mathrm{bc}$ & $69,00 \mathrm{abc}$ & $10,00 a b c$ & $70,00 \mathrm{abcd}$ & $19,60 \mathrm{abcd}$ & $17,56 a b$ \\
\hline K3U3 & $98,00 \mathrm{abc}$ & $55,00 \mathrm{a}$ & $71,50 \mathrm{abc}$ & $0,00 \mathrm{c}$ & $71,50 \mathrm{abc}$ & $20,02 a b c$ & $16,15 a b$ \\
\hline
\end{tabular}

Keterangan: Angka-angka yang diikuti huruf yang sama pada kolom yang sama tidak berbeda nyata pada uji DMRT taraf $5 \%$ 
(Balitkabi, 2016). Pada perlakuan tanpa vermikompos diperoleh bobot biji 10,08-21,98 g setara dengan $1,34-2,92$ ton ha $^{-1}$. Nilai ini memenuhi standar daya hasil kedelai varietas Anjasmoro pada aplikasi urea 50 $\mathrm{kg} \mathrm{ha}^{-1}$. Kombinasi vermikompos 15 ton ha- ${ }^{-1}$ dan pupuk urea dapat meningkatkan hasil kedelai dan memenuhi kebutuhan hara tanaman pada tanah berpasir.

Aplikasi dosis urea yang optimum saat kebutuhan hara $\mathrm{N}$ telah terpenuhi bagi tanaman kedelai akan meningkatkan pembentukan polong kedelai karena unsur ini berperan dalam pembentukan polong. Hasil penelitian Mayani dan Hapsoh (2011) menunjukkan aplikasi pupuk urea dosis $150 \mathrm{~kg} \mathrm{ha}^{-1}$ dan $200 \mathrm{~kg} \mathrm{ha}^{-1}$ memberikan hasil yang lebih rendah daripada dosis $110 \mathrm{~kg} \mathrm{ha}^{-1}$ pada jumlah polong per tanaman, hasil biji per tanaman, bobot tanaman segar, dan hasil biji kedelai per petak. Hal ini tidak sesuai dengan hasil penelitian Permanasari et al. (2014), yang menyatakan bahwa urea dosis $150 \mathrm{~kg} \mathrm{ha}^{-1}$ dapat meningkatkan jumlah polong per tanaman, tetapi tidak mencapai dosis $300 \mathrm{~kg} \mathrm{ha}^{-1}$. Selanjutnya pada penelitian Arizka et al. (2013), hasil dari aplikasi dosis urea $300 \mathrm{~kg} \mathrm{ha}^{-1}$ tidak berbeda nyata pada indeks panen, laju pengisian biji, dan bobot 100-butir kedelai.

Hasil dari tanaman kedelai adalah berupa polong yang berisi biji. Periode pengisian biji pada kedelai membutuhkan unsur N dan P (Ramadhani et al. 2016). Menurut Hanum (2010), meningkatnya nitrogen pada tanaman akan memengaruhi laju serapan P. Pembentukan jumlah polong akan mempengaruhi produksi kedelai. Polong yang dihasilkan dapat berupa polong hampa dan polong berisi (Xiang et al. 2012). Salah satu indikator hara telah diserap tanaman secara optimum adalah jumlah polong hampa lebih sedikit daripada jumlah polong isi (Chakma et al. 2015). Hal ini akan meningkatkan bobot biji kedelai.

Secara keseluruhan, proses vegetatif kedelai (variabel tinggi tanaman, jumlah daun, dan jumlah cabang) terbaik ialah pada pemberian pupuk vermikompos dosis 10 ton ha-1 dan 15 ton ha ${ }^{-1}$. Variabel jumlah daun kedelai menunjukkan hasil yang berbeda nyata pada pemberian berbagai dosis urea. Nilai pertumbuhan tertinggi diperoleh dari pemberian urea 100 $\mathrm{kg} \mathrm{ha}^{-1}$ dengan jumlah daun 28,87 helai. Akan tetapi, pada dosis (150 $\mathrm{kg} \mathrm{ha}^{-1}$ ) jumlah daun dan jumlah cabang tidak berbeda nyata dengan dosis $0 \mathrm{~kg} \mathrm{ha}^{-1}$ dan $50 \mathrm{~kg} \mathrm{ha}^{-1}$. Hal ini menunjukkan bahwa dosis $100 \mathrm{~kg}$ ha $^{-1}$ telah dapat memenuhi kebutuhan hara $\mathrm{N}$ bagi tanaman kedelai di tanah berpasir.

Kandungan $\mathrm{N}$ yang tergolong rendah pada tanah berpasir membuat tanaman kedelai menginginkan dosis vermikompos yang tinggi. Vermikompos dapat memperbaiki pertumbuhan dan kualitas hasil pertanian karena aktivitas mikroorganisme di dalam tanah serta terdapat unsur hara yang lambat tersedia (Dewi et al. 2012), dan kadar $N$ total pada vermikompos sangat tinggi. Pemupukan akan optimum jika diberikan dalam jumlah yang tepat serta pada kondisi lingkungan yang sesuai (Kelik 2010).

Pemenuhan kebutuhan hara $\mathrm{N}$ untuk pertumbuhan dan hasil kedelai dari urea $46 \%$ dalam $100 \mathrm{~kg}$ dan $1,65 \%$ pada vermikompos akan membantu meningkatkan kandungan $\mathrm{N}$ pada lahan berpasir yang sangat rendah $(0,04 \%)$. Sifat hara nitrogen mudah hilang (leaching) sehingga di dalam tanah jumlahnya sangat terbatas. Yoseftabar (2012) menyatakan bahwa pupuk nitrogen pada dosis $150 \mathrm{~kg} \mathrm{ha}^{-1}$ menunjukkan pertumbuhan dan hasil terbaik pada tanaman padi. Selain itu, penelitian Bruun et al. (2012) menemukan dosis pupuk N $300 \mathrm{~kg} \mathrm{ha}^{-1}$ + biochar $2 \%$ dapat mengurangi pencucian pada tanah berpasir. Dengan demikian, dapat dikatakan bahwa dosis $100 \mathrm{~kg} \mathrm{ha}^{-1}$ sudah mencukupi kebutuhan tanaman kedelai di lahan berpasir. Dosis yang tidak tinggi juga menguntungkan dalam pengurangan pupuk anorganik. Gourevitch (2018) menyarankan bahwa dosis aplikasi pupuk $\mathrm{N}$ yang optimum secara efisien ialah pada rentang $0 \mathrm{~kg}$ $\mathrm{ha}^{-1}-161 \mathrm{~kg} \mathrm{ha}^{-1}$. Sesuai dengan pendapat Lingga dan Marsono (2001) dalam Syahrudin (2011), disimpulkan bahwa unsur yang sangat penting untuk pertumbuhan tanaman adalah nitrogen sehingga perlu diberikan pada dosis yang cukup.

Perlakuan vermikompos 15 ton ha ${ }^{-1}$ dan urea $50 \mathrm{~kg}$ ha $^{-1}\left(\mathrm{~K}_{3} \mathrm{U}_{1}\right)$ yang tidak berbeda nyata dengan dosis urea $100 \mathrm{~kg} \mathrm{ha}^{-1}\left(\mathrm{U}_{2}\right)$ dan $150 \mathrm{~kg} \mathrm{ha}^{-1}\left(\mathrm{U}_{3}\right)$ memberikan hasil yang terbaik dalam hal biomassa kedelai, yaitu bobot kering tajuk mencapai 20,15 g (Tabel 2). Dosis vermikompos tidak memengaruhi bobot kering akar dan bobot bintil akar (Tabel 3). Sebaliknya, dosis urea mempengaruhi bobot kering akar dan bobot bintil akar dengan nilai tertinggi pada $100 \mathrm{~kg} \mathrm{ha}^{-1}$.

Tabel 3 Rataan jumlah daun, bobot kering akar, jumlah bintil akar, dan bobot bintil akar kedelai pada aplikasi pupuk vermikompos dan urea dengan dosis yang berbeda di tanah berpasir

\begin{tabular}{|c|c|c|c|c|}
\hline Perlakuan & Jumlah daun (helai) & Bobot kering akar (g) & $\begin{array}{l}\text { Jumlah bintil akar } \\
\text { (buah) }\end{array}$ & Bobot bintil akar (g) \\
\hline \multicolumn{5}{|l|}{ Vermikompos } \\
\hline $0\left(\mathrm{~K}_{0}\right)$ & $23,75 b$ & 12,40 & $115,00 \mathrm{ba}$ & 0,458 \\
\hline $5\left(K_{1}\right)$ & $22,75 b$ & 21,52 & $83,75 \mathrm{~b}$ & 0,402 \\
\hline $10\left(\mathrm{~K}_{2}\right)$ & $25,25 a b$ & 17,10 & $158,75 \mathrm{a}$ & 0,581 \\
\hline $15\left(\mathrm{~K}_{3}\right)$ & $27,50 \mathrm{a}$ & 18,43 & $165,00 \mathrm{a}$ & 0,636 \\
\hline \multicolumn{5}{|l|}{ Urea $\left(\mathrm{kg} \mathrm{ha}^{-1}\right)$} \\
\hline $0\left(\mathrm{U}_{0}\right)$ & $19,12 b$ & $15,45 b$ & $10,37 b$ & $0,563 b$ \\
\hline $50\left(U_{1}\right)$ & $20,25 \mathrm{~b}$ & $15,41 \mathrm{~b}$ & $10,25 \mathrm{~b}$ & $0,446 \mathrm{~b}$ \\
\hline $100\left(\mathrm{U}_{2}\right)$ & $28,87 \mathrm{a}$ & $24,88 \mathrm{a}$ & $17,37 \mathrm{a}$ & 0,936 a \\
\hline $150\left(\mathrm{U}_{3}\right)$ & $20,00 \mathrm{~b}$ & $15,46 b$ & $9,25 b$ & $0,132 \mathrm{c}$ \\
\hline
\end{tabular}

Keterangan: Angka-angka yang diikuti huruf yang sama pada kolom yang sama tidak berbeda nyata pada uji DMRT taraf $5 \%$ 
Akar merupakan bagian tanaman sebagai media penyerapan unsur hara untuk disalurkan ke seluruh bagian tanaman. Pemberian nitrogen yang cukup pada tanaman akan mempercepat laju pertumbuhan dan perkembangan akar. Pengaruh dosis urea cukup besar pada bobot kering tajuk, bobot kering akar, jumlah bintil akar, dan bobot bintil akar. Tanaman kedelai memiliki bintil akar sebagai bentuk dari simbiosis antara tanaman kedelai dan bakteri Rhizobium. Bakteri Rhizobium pada bintil akar berfungsi untuk mengikat unsur $\mathrm{N}_{2}$ bebas di udara (Kumalasari et al. 2013). Jumlah hara $\mathrm{N}$ tersedia pada saat tanam dapat memacu pertumbuhan akar rambut dan menginfeksi bakteri lebih cepat (Rosmarkam \& Yuwono 2002) sehingga aplikasi pupuk $\mathrm{N}$ yang cukup dapat meningkatkan jumlah dan bobot bintil akar.

\section{KESIMPULAN}

Dari hasil penelitian ini terdapat interaksi perlakuan dosis pupuk urea dan vermikompos pada variabel tinggi tanaman, jumlah cabang, jumlah polong isi, jumlah polong hampa, jumlah polong total, dan bobot kering tajuk. Interaksi antara dosis vermikompos 15 ton ha $^{-1}$ dan urea $50 \mathrm{~kg} \mathrm{ha}^{-1}$ memberikan hasil tertinggi pada jumlah polong total dan bobot biji. Pemberian urea $100 \mathrm{~kg} \mathrm{ha}^{-1}$ dan vermikompos 10 ton ha-1 memberikan tinggi tanaman kedelai terbaik dan perlakuan urea $150 \mathrm{~kg} \mathrm{ha}^{-1}$ dan vermikompos 15 ton ha $^{-1}$ membentuk cabang terbanyak.

\section{DAFTAR PUSTAKA}

Afandi FN, Siswanto B, Nuraini Y. 2017. Pengaruh pemberian berbagai jenis bahan organik terhadap sifat kimia tanah pada pertumbuhan dan produksi tanaman ubi jalar di Entisol Ngrangkah Pawon, Kediri. Jurnal Tanah dan Sumberdaya Lahan. 2(2): 237-244. https://jtsl.ub.ac.id/index.php/jtsl/article/vi ew/134

Arizka PS, Nurmauli N, Nurmiaty Y. 2013. Efisiensi dosis pupuk NPK majemuk dalam meningkatkan hasil kedelai varietas grobogan. Jurnal Agrotek Tropika. 1(2).

[Balitkabi] Balai Penelitian Tanaman Aneka Kacang dan Umbi. 2016. Deskripsi varietas unggul kedelai 1918-2016. http://balitkabi.litbang.pertanian.go.id/ wp-content/uploads/2016/09/kedelai.pdf

Bruun EW, Petersen C, Strobel BW, HauggaardNielsen H. 2012. Nitrogen and carbon leaching in repacked sandy soil with added fine particulate biochar. Soil Science Society of America Journal. 76(4): 1142-1148. https://doi.org/10.2136/sssaj201 1.0101

Chakma M, Ali MS, Khaliq QA, Rahaman MA, Talukdar M. 2015. The effect of chemical fertilizers on the yield performance of soybean genotypes. Bangladesh Research Publications Journal. 11(3): 187-192.

Dewi WS, Sumarno, Rossati S. 2012. Potensi cacing tanah eksotik endogenik Pontiscolex corethrurus untuk produksi vermikompos granul (Vermigran) berbasis bahan organik lokal. Jurnal Caraka Tani. 27(1): 100-104. https://doi.org/10.20961/carakatani .$v 27 i 1.14364$

Gourevitch JD, Keeler BL, Ricketts TH. 2018. Determining socially optimal rates of nitrogen fertilizer application. Agriculture, Ecosystems \& Environment. 254: 292-299. https://doi.org/10.1016 /j.agee.2017.12.002

Hanum C. 2010. Pertumbuhan dan hasil kedelai yang diasosiasikan dengan rhizobium pada zona iklim kering E (Klasifikasi Oldeman). Bionatura. 12(3): 176-183. http://jurnal.unpad.ac.id/bionatura/article /view/7692

Hindersah R, Nabila A, Yuniarti A. 2019. Pengaruh vermikompos dan pupuk majemuk terhadap ketersediaan fosfat tanah dan hasil kentang (Solanum tuberosum L.) di andisols. Agrologia. 8(1): 21-27. https://doi.org/10.30598/a.v8i1.874

Kelik W. 2010. Pengaruh kosentrasi dan frekuensi pemberian pupuk organik cair hasil perombakan anaerob limbah makanan terhadap pertumbuhan tanaman sawi (Brassica juncea L.). Jurnal Agrosains. 19(4): 11-134.

Kementerian Pertanian. 2016. Outlook komoditas kedelai 2016. Jakarta Selatan (ID): Pusat Data dan Sistem Informasi.

Kumalasari ID, Astuti ED, Prihastanti E. 2013. Pembentukan bintil akar tanaman kedelai (Glycine max (L) Merrill) dengan perlakuan jerami pada masa inkubasi yang berbeda. Jurnal Sains dan Matematika. 21(4): 103-107. https://ejournal.undip. ac.id/index.php/sm/article/view/8046

Mayani N, Hapsoh. 2011. Potensi rhizobium dan pupuk urea untuk meningkatkan produksi kedelai (Glycine max (L)) pada lahan bekas sawah. IImu Pertanian Kultivar. 5(2): 67-75.

Munnoli PM, Bhosle S. 2011. Water-holding capacity of earthworms vermicompost made of sugar industry waste (press mud) in mono- and polyculture vermireactors. Enviromentalist. 31: 394-400. https ://doi.org/10.1007/s10669-011-9353-6

Pambudi S. 2013. Budidaya dan khasiat kedelai. Yogyakarta (ID): Pustaka Baru Press.

Permanasari D, Irfan M, Abizar. 2014. Pertumbuhan dan hasil kedelai (Glycine Max (L.) Merill) dengan pemberian Rhizobium dan pupuk urea pada media gambut. Jurnal Agroteknologi. 5(1): 29-34. 
Rajiman, Yudono P, Sulistyaningsih E, Hanudin E. 2008. Pengaruh pembenah tanah terhadap sifat fisika dan hasil bawang merah pada lahan pasir pantai Bugel Kabupaten Kulon Progo. Agrin: Agricultural Reseach and Information. 12(1): 67-77. https://repository.ugm.ac.id/id/eprint/32410

Ramadhani RH, Roviq M, Maghfoer MD. 2016. Pengaruh sumber pupuk nitrogen dan waktu pemberianurea pada pertumbuhan dan hasil tanaman jagung manis (Zea mays. Sturt. var. saccharata). Jurnal Produksi Tanaman. 4(1): 8-15. http://protan.studentjournal.ub.ac.id/index.php/prot an/article/view/254

Rosmarkam A, Yuwono NW. 2002. Ilmu kesuburan tanah. Yogyakarta (ID): Penerbit Kanisius.

Syahrudin. 2011. Respon tanaman seledri (Apium graveolus L.) terhadap pemberian beberapa macam pupuk daun pada tiga jenis tanah. Jurnal Agri Peat. 12(1).

Tauhidah NA, Rosyidah A, Nurhidayati. 2018. Efek pemberian kombinasi vermikompos berbehan aditif biochar dan pupuk anorganik terhadap pertumbuhan dan kadar hara $\mathrm{N}, \mathrm{P}$ dan $\mathrm{K}$ tanaman brokoli (Brassica oleraceae L.) pada tanah berpasir. Jurnal Folium. 2(1): 42-54.

Xiang DB, Yong TW, Yang WY, Gong WZ, Cui L, Lei T. 2012. Effect of phosphorus and potassium nutrition on growth and yield of soybean in relay strip intercropping system. Scientific Research and Essays. 7(3): 342-351.

Yoseftabar S. 2012. Effect of nitrogen and phosphorus fertilizer on growth and yield rice (Oryza sativa L). International Journal of Agronomy and Plant Production. 3(12): 579-584. 